\title{
Complete trophic segregation between South Georgian and common diving petrels during breeding at Iles Kerguelen
}

\author{
Pierrick Bocher ${ }^{1,2}$, Yves Cherel ${ }^{1, *}$, Keith A Hobson ${ }^{3}$ \\ ${ }^{1}$ Centre d'Etudes Biologiques de Chizé, UPR 1934 du Centre National de la Recherche Scientifique, \\ 79360 Villiers-en-Bois, France \\ ${ }^{2}$ Laboratoire de Biologie et Environnement Marins, EA 1220 de l'Université de La Rochelle, 17026 \\ La Rochelle Cedex, France \\ ${ }^{3}$ Prairie and Northern Wildlife Research Centre, Environment Canada, Saskatchewan, S7N 0X4, Canada
}

\begin{abstract}
The food and feeding ecology of the 2 closely related and sympatric species of diving petrels Pelecanoides georgicus and P. urinatrix was investigated over 3 consecutive summers at Iles Kerguelen, southern Indian Ocean, where they breed in large numbers. The 2 species fed consistently on different crustacean prey during the $3 \mathrm{yr}$, the diet of $P$. georgicus being dominated by the euphausiid Thysanoessa sp. (50\% of the number of prey and $81 \%$ of the reconstituted mass) and the copepod Calanoides acutus (45 and 10\%, respectively), and that of $P$. urinatrix by the hyperiid Themisto gaudichaudii (61 and $91 \%$, respectively) and the copepod Paraeuchaeta antarctica (21 and $9 \%$, respectively). Chicks of $P$. georgicus were fed less frequently (on $81 \mathrm{vs} 97 \%$ of nights, respectively) with more digested prey items than chicks of $P$. urinatrix. This, together with visual observations at sea and the known biogeography of their prey, shows a complete horizontal spatial segregation between the 2 species of diving petrels, with $P$. urinatrix foraging in coastal waters in the close vicinity of their colonies and $P$. georgicus in more offshore waters. Maximum depth gauges indicate an incomplete vertical segregation in the water, $P$. georgicus reaching on average depths closer to the surface than $P$. urinatrix ( 26 vs $33 \mathrm{~m}$, respectively). The stable-carbon and -nitrogen isotopic composition of chick food and chick feathers differed between the 2 species, thus emphasising the segregation at sea during the breeding period when adult birds are central-place foragers. The stable isotopic composition $\left(\delta^{13} \mathrm{C}\right.$ and $\left.\delta^{15} \mathrm{~N}\right)$ of adult feathers were, however, identical in both species, indicating no trophic segregation during the moulting (inter-breeding) period when birds feed in offshore waters.
\end{abstract}

KEY WORDS: Calanoides acutus $\cdot$ Paraeuchaeta antarctica $\cdot$ Pelecanoides $\cdot$ Seabirds $\cdot$ Stable-carbon isotopes $\cdot$ Stable-nitrogen isotopes $\cdot$ Themisto gaudichaudii $\cdot$ Thysanoessa

\section{INTRODUCTION}

In the Southern Hemisphere, the order Procellariiformes (albatrosses, petrels, storm petrels and diving petrels) dominates the seabird community in terms of the number of species and the number of individuals. They show a wide range in size and in various ecological and physiological adaptations to the marine environment (Warham 1990, 1996). The highest degree of

*E-mail:cherel@cebc.cnrs.fr diversity is reached at some subantarctic and periAntarctic islands, such as Iles Crozet and Iles Kerguelen, and at South Georgia (Croxall et al. 1984, Jouventin et al. 1984, Warham 1990, 1996). Altogether 35 bird species, including 24 species of Procellariiformes, number 6.5 to 10.9 million breeding pairs each year at Kerguelen (Weimerskirch et al. 1989). Five species of small burrowing petrels account for about $66 \%$ of the total number of birds of the archipelago, South Georgian (Pelecanoides georgicus) and common (P. urinatrix) diving petrels, thin-billed (Pachyptila belcheri) 
and Antarctic ( $P$. desolata) prions, and blue petrel (Halobaena caerulea). It was estimated that the 5 species together consume annually 0.6 million tonnes of marine resources (Guinet et al. 1996). Unlike at Iles Crozet (Ridoux 1994) and South Georgia (Croxall \& Prince 1980), however, almost nothing is known about the diets of petrels at Iles Kerguelen (Chaurand \& Weimerskirch 1994, Weimerskirch et al. 1999). We have consequently studied their food and feeding ecology during 3 consecutive breeding seasons: first, to examine the relationships between petrels and the marine environment surrounding Iles Kerguelen and, second, to investigate trophic segregation among a community which includes closely related species like prions and diving petrels.

Among procellariform seabirds, diving petrels have very distinctive and homogeneous morphology and behaviour, being easily recognised by their small size and compact shape, which are, in turn, related to the underwater pursuit of their food by wing propulsion (Marchant \& Higgins 1990, Warham 1990). The 4 species of diving petrels live in cold or cool waters of the Southern Hemisphere (Warham 1990). Among them, Pelecanoides georgicus and $P$. urinatrix have a circumpolar range and breed sympatrically in several archipelagos of the Southern Ocean (Marchant \& Higgins 1990, Warham 1990), including Iles Kerguelen, where the populations of $P$. georgicus and $P$. urinatrix have been estimated to amount to 1-2 million and 0.5-1 million breeding pairs each year, respectively (Weimerskirch et al. 1989). The 2 species segregate by breeding in different terrestrial habitats at different times (Warham 1990). At Iles Kerguelen, P. urinatrix breeds on average 3 wk later than P. georgicus (Paulian 1953, Weimerskirch et al. 1989), a phenology contrasting with that found elsewhere (Payne \& Prince 1979, Imber \& Nilsson 1980, Jouventin et al. 1985, Mougin 1985). Weimerskirch et al. (1989) hypothesise that this difference is due to different oceanographic and, thus, feeding conditions, $P$. urinatrix being assumed to forage in more sheltered coastal areas at Kerguelen and in more offshore zones elsewhere.

The diets of Pelecanoides georgicus and P. urinatrix have been investigated in detail at 2 localities during the breeding season. At South Georgia, food is dominated by euphausiids and copepods (Payne \& Prince 1979, Reid et al. 1997), while at Iles Crozet, they feed mainly on euphausiids and amphipods (Ridoux 1994). At each locality, the prey species of the 2 diving petrels are essentially similar, with differences occurring in their proportions by number and by mass (Ridoux 1994, Reid et al. 1997). Dietary differences, chick feeding rates and ship-based observations suggest an incomplete horizontal spatial segregation at sea during the breeding period, $P$. georgicus tending to feed more offshore and $P$. urinatrix in more inshore waters (Jouventin et al. 1988, Reid et al. 1997). A partial vertical segregation was also hypothesised (Reid et al. 1997), since $P$. urinatrix equipped with capillary-tube depth gauges at Kerguelen dived deeper than $P$. georgicus at South Georgia (Prince \& Jones 1992, Chastel 1994). However, the 2 studies were performed at different localities, during 2 different years, and the work on $P$. georgicus involved only a few birds (Prince \& Jones 1992).

The main objective of the present study was to investigate the trophic segregation between the 2 closely related species of diving petrels Pelecanoides georgicus and P. urinatrix breeding at Iles Kerguelen. Prey species, chick feeding frequency and food mass were recorded over 3 consecutive breeding years (1994/95, 1995/96 and 1996/97), together with the diving performances of the 2 species which were investigated at the same locality for the first time. We also focused on the foraging ecology during the inter-breeding period, for which no other information is available, through stable isotopic analyses of adult flight feathers. Since keratin is metabolically inert after synthesis (Kelly \& Finch 1998), the stable-carbon and -nitrogen isotopic composition of feathers are markers potentially useful in investigating the birds' trophic relationships and foraging areas during the moulting period (Cherel et al. 2000). In seabirds, moult mainly occurs outside the breeding season. In diving petrels, synthesis of flight feathers takes place after the breeding season, but it may begin in late chick-rearing for $P$. urinatrix, while no overlap between breeding and moult was observed for P. georgicus (Payne \& Prince 1979, Marchant \& Higgins 1990).

\section{METHODS}

Study sites and birds. Fieldwork was carried out during 3 consecutive summer seasons (1994/95, 1995/96 and 1996/97) in the Golfe du Morbihan, eastern Kerguelen Archipelago (southern Indian Ocean). The 2 species of diving petrels nest in different habitats, Pelecanoides georgicus digging their burrows in bare soil or where plant cover is poor, and $P$. urinatrix in deep soils with ample plant cover, particularly under Kerguelen cabbage (Pringlea antiscorbutica) (Weimerskirch et al. 1989). The study colonies were located at 2 adjacent islands where large populations of diving petrels breed, $P$. georgicus at Ile Verte $\left(49^{\circ} 31^{\prime} \mathrm{S}\right.$, $\left.70^{\circ} 04^{\prime} \mathrm{E}\right)$ and $P$. urinatrix at Ile Mayes $\left(49^{\circ} 28^{\prime} \mathrm{S}\right.$, $69^{\circ} 57^{\prime}$ E) (Fig. 1). Each species was studied each year during 10 to 12 consecutive days, corresponding to the middle of the chick-rearing period which lasts 50 to $55 \mathrm{~d}$ in these species (Jouventin et al. 1985, Weimers- 


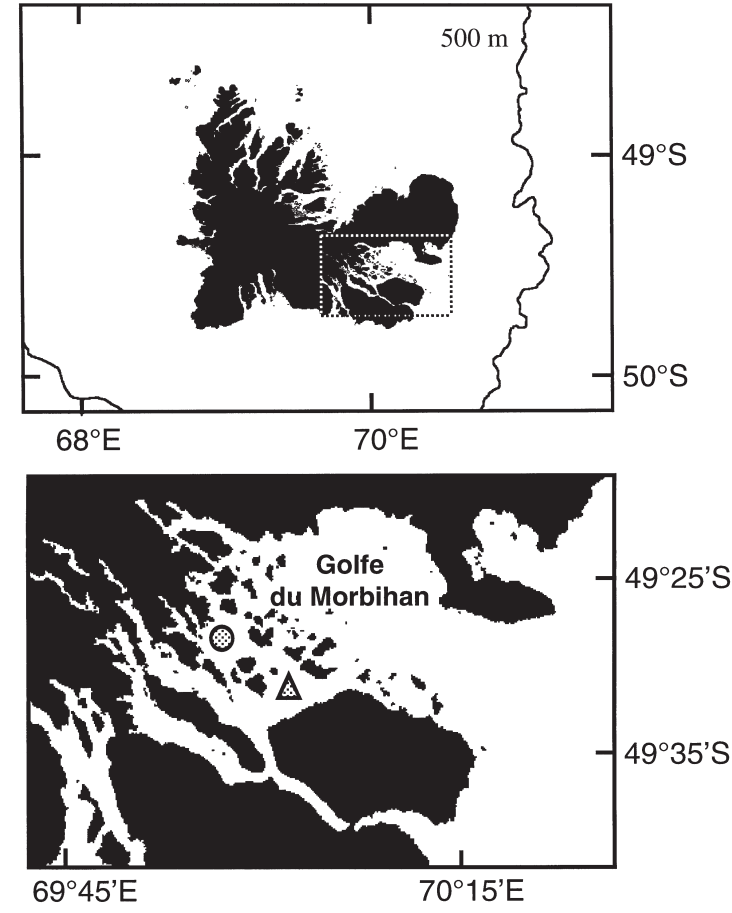

Fig. 1. Pelecanoides spp. Map of Iles Kerguelen (upper panel) and details of the eastern part of the archipelago (lower panel) showing the location of the study colonies within the Golfe du Morbihan (circle, Ile Mayes; triangle, Ile Verte)

kirch et al. 1989). In the Golfe du Morbihan $P$. urinatrix breeds on average later than $P$. georgicus; consequently, the 2 species were studied at an interval of $3 \mathrm{wk}, P$. georgicus in January and $P$. urinatrix in February (see Table 1).

Food mass and feeding frequency. Eighteen to 34 randomly selected chicks of each species were monitored each year during the study period (Table 1). Burrows were marked with numbered wood stakes; in the case of deep burrows, an opening was dug out over the nesting chamber and covered with rock and earth slabs, thus facilitating access to the birds. Chicks were weighed (accuracy $\pm 2 \mathrm{~g}$ ) twice daily, before dusk at 19:00 h (local time) when adults were at sea, and at 00:00 h by which most adult birds visiting the colony at night had fed their single chick. An increase in body mass of at least $2 \mathrm{~g}$, either between the 2 successive weighings within a given night, or between weighings at midnight and the following evening, was considered to represent a feeding event. However, food mass delivered by adults to chicks during a given night was calculated as the difference between a chicks' body mass at 19:00 and 00:00 h only. Chick feeding frequency was calculated as the ratio between the number of nights with feedings (sum for all the chicks) divided by the total number of nights with weighings (sum for all the chicks) (Table 1). Note that $10.0 \%$ and $0.6 \%$ of feeding events occurred after midnight for Pelecanoides georgicus and $P$. urinatrix, respectively. No attempt was made to differentiate between single and double meals given by 1 or both parents within the same night, because the sampling protocol could not distinguish 1 feed and 2 (Granadeiro et al. 1999).

Dietary analyses. Outside the study colony, diving petrels were caught by mist netting at night or in burrows fitted with trap doors at the entrance to retain the adult before the chick was fed. Food samples were collected using a stomach lavage technique similar to that described by Reid et al. (1997) and Bocher et al. (2000). A supple plastic tube $(2.4 \mathrm{~mm}$ external, $0.8 \mathrm{~mm}$ internal diameter) was inserted into the stomach, and water slowly introduced via a syringe. The tube was removed when the anterior alimentary tract and buccal cavity were full of water. The petrel was then immediately inverted over a sieve, and its abdomen was gently massaged to facilitate regurgitation. Bird stomachs were evacuated no more than 3 times, even if water still contained prey items. After lavaging, diving petrels were measured, banded and placed in a box to recover, and were thereafter released at their capture site. No individual bird was sampled more than once in the study. Diet samples were drained to remove excess water, immediately frozen at $-20^{\circ} \mathrm{C}$, and returned to Chizé, France, for analysis. In the laboratory, each sample was thawed, drained a second time, and placed in a large flat-bottomed tray. Fresh remains were divided into broad prey classes (crustaceans and fish), which were weighed to estimate their proportions by fresh mass in the diet.

Total numbers of common and rare prey items were counted in each individual whole sample. Prey were identified using keys in Boschi et al. (1969), Baker et al. (1990), Williams \& McEldowney (1990), Razouls (1994), Ledoyer (1995) and Vinogradov et al. (1996), and by comparison with material held in our own reference collection. Thirty to 60 items (either intact specimens and/or intact eyes) of the main prey species were randomly selected per dietary sample. Total length and eye diameter were determined using an ocular scale in a binocular microscope. Total length (TL) of amphipods, euphausiids and copepods was measured from the front of eye to the tip of uropods, from the tip of rostrum to the tip of uropods, and from the tip of rostrum to the furca, respectively. Total length was estimated from eye diameter measurements by the use of allometric equations (Ridoux 1994, authors' unpubl. data). In order to estimate the composition by mass of the diet, the body mass of crustaceans and fish was estimated from body length using published relationships (Hindell 1988, Mizdalski 1988, Williams \& McEldowney 1990, Ridoux 1994) and our own equations. 
Where equations for certain species were not available, estimates were made from equations for closely related species or for species with a similar morphology. The reconstructed mass of each taxon for each sample was calculated from the average wet body mass for the species in the sample. The value was then multiplied by the number of individuals in the sample, and the resulting value was pooled with those calculated for the same taxon in the other samples. The calculated masses for all the different taxa were consequently pooled, and the reconstituted proportion by mass of each taxon then calculated as the percentage it represented in the total reconstituted mass.

Maximum dive depths. Maximum depths reached by diving petrels were investigated using capillarytube depth gauges (Burger \& Wilson 1988), following Bocher et al. (2000). Briefly, a 10 to $12 \mathrm{~cm}$ length of plastic tube (Tygon brand; internal diameter, $0.8 \mathrm{~mm}$ ) was coated inside with icing sugar and sealed at 1 extremity. The tube was fitted on the back feathers using a waterproof adhesive tape. Each recorder weighed $0.6 \mathrm{~g}$, i.e. $<0.5 \%$ of the mean body mass. Maximum dive depth was estimated by the equation: $d=10.08\left[\left(L_{\mathrm{s}} / L_{\mathrm{d}}\right)-1\right]$, where $d$ is the maximum depth (m), $L_{\mathrm{s}}$ is the initial length $(\mathrm{mm})$ of undissolved sugar, and $L_{\mathrm{d}}$ the length $(\mathrm{mm})$ on recovery (accuracy \pm $0.5 \mathrm{~mm}$ ) (Burger \& Wilson 1988).

Stable isotope analysis. Feathers were collected from intact wings of adult diving petrels killed by subantarctic skuas Catharacta antarctica lönnbergi early in the breeding season, and chick feathers were taken from the tip of the first few primaries from live fledglings in their burrows.

Before isotopic analysis, food samples were freeze dried or dried in an oven at $+60^{\circ} \mathrm{C}$ and ground to a fine powder in an analytical mill. Lipids were then removed using a Soxhlet apparatus with chloroform solvent for 4 to $6 \mathrm{~h}$. Feathers were cleaned of surface contaminants using a 2:1 chloroform:ether rinse, air dried, and then cut with stainless steel scissors into small fragments.

Stable-carbon and-nitrogen isotope assays were performed on $1 \mathrm{mg}$ subsamples of homogenised materials by loading into tin cups and combusting at $1800^{\circ} \mathrm{C}$ in a Robo-Prep elemental analyser. Resultant $\mathrm{CO}_{2}$ and $\mathrm{N}_{2}$ gases were then analysed using an interfaced Europa 20:20 continuous-flow isotope ratio mass spectrometer (CFIRMS) with every 5 unknowns separated by 2 laboratory standards. Stable isotope abundances were expressed in $\delta$ notation as the deviation from standards in parts per thousand (\%) according to the following equation:

$$
\delta X=\left[\left(R_{\text {sample }} / R_{\text {standard }}\right)-1\right] \times 1000
$$

where $X$ is ${ }^{13} \mathrm{C}$ or ${ }^{15} \mathrm{~N}$ and $R$ is the corresponding ratio ${ }^{13} \mathrm{C} /{ }^{12} \mathrm{C}$ or ${ }^{15} \mathrm{~N} /{ }^{14} \mathrm{~N}$. The $R_{\text {standard }}$ values were based on

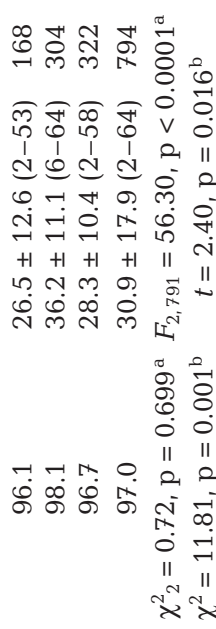

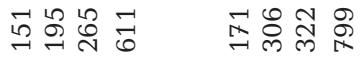

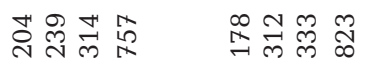

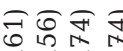

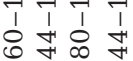

in $\infty$ i

$+1+1+1+1$

큐용

$\exists ㅇ ㅢ ㅋ$

कृषఠ

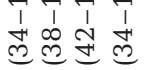

N $\infty \prod_{\infty}^{\infty} \infty$

$+1+1+1+1$

요의

ช。ㅀㅀ

11 15

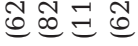

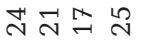

$+1+1+1+1$

응 욕욤

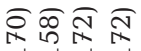

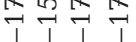

平证足这

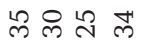

$+1+1+1+1$

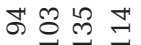

고ำำ

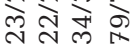

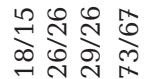

ฐู้

뇽요요

S.

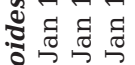

สี 슈유

0 0 ?

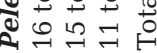


the PeeDee Belemnite (PDB) for ${ }^{13} \mathrm{C}$ and atmospheric $\mathrm{N}_{2}$ (air) for ${ }^{15} \mathrm{~N}$. Replicate measurements of internal laboratory standards (albumen) indicate measurement errors of $\pm 0.1 \%$ and $\pm 0.3 \%$ or stable-carbon and -nitrogen isotope measurements, respectively.

Statistics. Data were analysed statistically using SYSTAT 9 for WINDOWS (Wilkinson 1999). Values are means \pm SD, significance at 0.05 level.

\section{RESULTS}

\section{Pelecanoides georgicus}

Food mass and feeding frequency

Chicks of Pelecanoides georgicus were fed at least 1 meal by their parents on $81 \%$ of the nights, with no significant differences among the 3 yr (Table 1). When fed, chicks received on average of $29 \mathrm{~g}$ of food per night, with, again, no significant interannual differences. The decrease in the number of chicks to the end of the study periods was due to predation by subantarctic skuas on chicks located in shallow burrows. When taking into account the chicks followed during the whole study period only, the overall mass gain of chicks was $20 \pm 25 \mathrm{~g}$ in 10 to $12 \mathrm{~d}$, with no significant differences among years $(18 \pm 21,18 \pm 30$ and $23 \pm 26$ $\mathrm{g}$ for January 1995, 1996 and 1997, respectively, 1-way ANOVA, $\left.F_{2,68}=0.33, \mathrm{p}=0.718\right)$. The large range in mass of the chicks was due to the poorly synchronised breeding cycle within pairs in both species of diving petrels (Weimerskirch et al. 1989, authors' unpubl. data).

The mean adult body mass (before stomach lavage) of Pelecanoides georgicus was $141 \mathrm{~g}$, and it did not differ significantly among years $\left(F_{2,94}=1.36, \mathrm{p}=0.263\right)$. The wet mass of the 83 food samples averaged $11 \mathrm{~g}$, with significant differences among years $\left(F_{2,80}=3.92\right.$, $\mathrm{p}=0.024)$. The food samples collected in 1995 were lower in mass than those collected in 1996 (post Hoc Tukey HSD multiple comparison test, $p=0.022$ ) (Table 2). The mass of dietary samples was by far lower than that of the food mass measured by weighing chicks, because the stomach lavage technique is not very effective in diving petrels, confirming the previous observations of Reid et al. (1997).

\section{Diet}

Pelecanoides georgicus fed almost exclusively on crustaceans (99\% and $98 \%$ by fresh and reconstituted masses of the overall diet, respectively) and on fish which accounted for the remaining 1 to $2 \%$. The proportions of crustaceans and fish were similar for the 3 consecutive seasons (Table 2). Crustaceans occurred in $100 \%$ of the food samples, and dominated by number and by mass in all of them.

A total of 45153 prey items was recovered from 83 samples and included 45065 crustaceans (99.8\%) and only 88 fish $(0.2 \%)$. The fish prey were mainly postlarval animals too small and too digested to be determined. Overall, 12 species of crustaceans and 2 species of fish were identified (Table 3). By far, the diet was dominated by the euphausiid Thysanoessa sp., which occurred in all the samples and accounted for $50 \%$ of the total number of prey and $81 \%$ of the food by estimated reconstituted mass. The copepod Calanoides acutus ranked second ( $45 \%$ by number and $10 \%$ by mass); other common but minor items were the hyperiids Themisto gaudichaudii (which dominated by number and reconstituted mass in 2 samples) and Primno macropa, and the large calanoid Rhincalanus gigas. Rare to very rare prey items included 7 other crustacean species (Table 3 ).

Table 2. Pelecanoides spp. Birds' body mass (before stomach lavage), mass of food samples and broad prey class composition of the diet during 3 consecutive chick-rearing periods. Values are means \pm SD with ranges in parentheses

\begin{tabular}{|c|c|c|c|c|c|c|}
\hline \multirow{2}{*}{ Study period } & \multicolumn{2}{|l|}{ Birds } & \multicolumn{2}{|c|}{ Food sample mass } & \multicolumn{2}{|c|}{ Prey class ( $\%$ by fresh mass) } \\
\hline & Mass $(g)$ & Ind. (n) & Mass $(g)$ & Samples (n) & Crustaceans & Fish \\
\hline \multicolumn{7}{|c|}{ Pelecanoides georgicus } \\
\hline 1995 & $139 \pm 13(116-168)$ & 48 & $8.6 \pm 4.5(1.9-17.4)$ & 30 & 99.8 & 0.2 \\
\hline 1996 & $144 \pm 10(128-166)$ & 27 & $12.1 \pm 6.0(5.3-23.0)$ & 29 & 99.1 & 0.9 \\
\hline 1997 & $139 \pm 11(120-162)$ & 22 & $11.2 \pm 3.7(7.2-17.7)$ & 24 & 98.9 & 1.1 \\
\hline Total & $141 \pm 12(116-168)$ & 97 & $10.6 \pm 5.0(1.9-23.0)$ & 83 & 99.2 & 0.8 \\
\hline \multicolumn{7}{|c|}{ Pelecanoides urinatrix } \\
\hline 1995 & $157 \pm 11(124-190)$ & 54 & $14.5 \pm 3.6(6.5-21.9)$ & 29 & 100.0 & $<0.1$ \\
\hline 1996 & $151 \pm 9(138-168)$ & 32 & $10.6 \pm 4.4(3.9-25.1)$ & 32 & 100.0 & 0.0 \\
\hline 1997 & $151 \pm 12(130-181)$ & 23 & $11.2 \pm 3.0(5.7-17.3)$ & 20 & 100.0 & 0.0 \\
\hline Total & $154 \pm 11(124-190)$ & 109 & $12.1 \pm 4.2(3.0-25.1)$ & 81 & 100.0 & $<0.1$ \\
\hline
\end{tabular}


Table 3. Pelecanoides georgicus. Frequency of occurrence, number, reconstituted mass and length of prey items recovered from stomach contents of $P$. georgicus during chick-rearing (total for all 83 samples pooled)

\begin{tabular}{|c|c|c|c|c|c|c|c|c|c|}
\hline \multirow[t]{2}{*}{ Prey species } & \multicolumn{2}{|c|}{$\begin{array}{l}\text { Occurrence } \\
\text { in stomachs }\end{array}$} & \multicolumn{2}{|c|}{ Number } & \multicolumn{2}{|c|}{$\begin{array}{l}\text { Reconstituted } \\
\text { mass }\end{array}$} & \multicolumn{3}{|c|}{$\begin{array}{l}\text { Body length } \\
\text { (mm) }\end{array}$} \\
\hline & (n) & $(\%)$ & (n) & $(\%)$ & $(g)$ & $(\%)$ & Mean & Range & (n) \\
\hline Crustaceans & 83 & 100.0 & 45065 & 99.8 & 495.1 & 98.0 & & & \\
\hline \multicolumn{10}{|l|}{ Euphausiacea } \\
\hline Euphausia vallentini & 4 & 4.8 & 14 & $<0.1$ & 0.9 & 0.2 & $21.5 \pm 2.8$ & $17.8-26.3$ & 12 \\
\hline Euphausia sp. & 13 & 15.7 & 13 & $<0.1$ & 1.2 & 0.2 & $23.2 \pm 6.3$ & $11.1-32.0$ & 12 \\
\hline Thysanoessa macrura/vicina & 83 & 100.0 & 22730 & 50.3 & 408.5 & 80.8 & $14.9 \pm 2.7$ & $3.4-23.4$ & 2423 \\
\hline \multicolumn{10}{|l|}{ Amphipoda } \\
\hline Orchomenopsis sp. & 1 & 1.2 & 1 & $<0.1$ & $<0.1$ & $<0.1$ & & & \\
\hline Hyperoche luetkenides & 4 & 4.8 & 4 & $<0.1$ & 0.2 & $<0.1$ & 13.5 & $13.1-13.9$ & 2 \\
\hline Themisto gaudichaudii & 24 & 28.9 & 692 & 1.5 & 17.4 & 3.4 & $11.1 \pm 1.6$ & $6.9-16.1$ & 240 \\
\hline Primno macropa & 55 & 66.3 & 615 & 1.4 & 12.3 & 2.4 & $10.1 \pm 3.2$ & $3.4-18.8$ & 268 \\
\hline Unidentified amphipods & 4 & 4.8 & 4 & $<0.1$ & 0.1 & $<0.1$ & & & \\
\hline \multicolumn{10}{|l|}{ Copepoda } \\
\hline Calanus simillimus & 6 & 7.2 & 15 & $<0.1$ & $<0.1$ & $<0.1$ & $3.0 \pm 0.2$ & $2.6-3.4$ & 9 \\
\hline Calanoides acutus & 47 & 56.6 & 20074 & 44.5 & 49.8 & 9.9 & $4.0 \pm 0.3$ & $2.7-4.9$ & 745 \\
\hline Rhincalanus gigas & 35 & 42.2 & 828 & 1.8 & 4.7 & 0.9 & $6.0 \pm 0.7$ & $4.4-8.4$ & 391 \\
\hline Drepanopus pectinatus & 2 & 2.4 & 2 & $<0.1$ & $<0.1$ & $<0.1$ & 2.1 & & 1 \\
\hline Paraeuchaeta antarctica & 2 & 2.4 & 3 & $<0.1$ & $<0.1$ & $<0.1$ & $4.2 \pm 0.5$ & $3.6-4.5$ & 2 \\
\hline Unidentified copepods & 9 & 10.8 & 12 & $<0.1$ & $<0.1$ & $<0.1$ & 3.2 & $3.1-3.2$ & 2 \\
\hline \multicolumn{10}{|l|}{ Cirripedia } \\
\hline Lepas australis (cypris larvae) & 18 & 21.7 & 58 & 0.1 & $<0.1$ & $<0.1$ & $2.6 \pm 0.2$ & $2.4-3.0$ & 38 \\
\hline Fish & 23 & 27.7 & 88 & 0.2 & 10.2 & 2.0 & & & \\
\hline \multicolumn{10}{|l|}{ Myctophidae } \\
\hline Krefftichthys anderssoni & 2 & 2.4 & 3 & $<0.1$ & 3.9 & 0.8 & 51.7 & $51.0-52.4$ & 2 \\
\hline \multicolumn{10}{|l|}{ Nototheniidae } \\
\hline Notothenia rossii (pelagic stage) & 6 & 7.2 & 6 & $<0.1$ & 2.3 & 0.5 & 32.4 & $31.9-32.9$ & 2 \\
\hline Unidentified postlarvae & 16 & 19.3 & 79 & 0.2 & 4.0 & 0.8 & & & \\
\hline Total & & & 45153 & 100.0 & 505.3 & 100.0 & & & \\
\hline
\end{tabular}

Pelecanoides georgicus
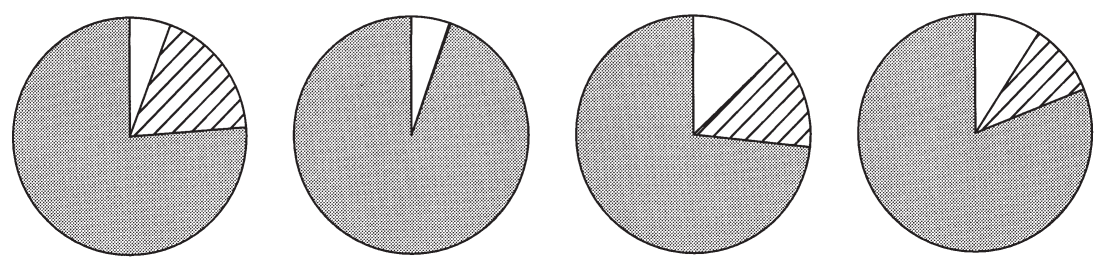

Pelecanoides urinatrix

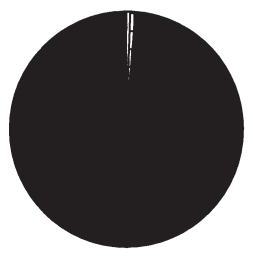

1995

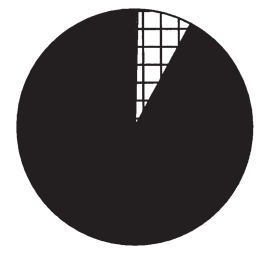

1996

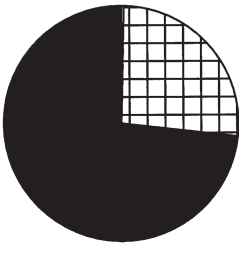

1997

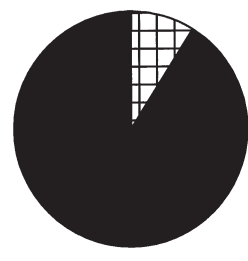

Total

Thysanoessa sp.

Themisto gaudichaudii

Calanoides acutus

Paraeuchaeta antarctica Others

Fig. 2. Pelecanoides spp. Composition by reconstituted mass of the diet during 3 consecutive chick-rearing periods 
Thysanoessa sp. prevailed by number and by mass in $78 \%(n=65)$ and $92 \%(n=76)$ of the samples, respectively. It was the dominant prey every season, accounting for 73 to $95 \%$ of the diet by reconstituted mass (Fig. 2). Two size-classes of Thysanoessa sp. were eaten by Pelecanoides georgicus, small individuals (3 to $8 \mathrm{~mm}$ TL) with no clear mode, and larger individuals (9 to $24 \mathrm{~mm}$ ) with a mode at 14 to $15 \mathrm{~mm}$ TL which formed the dominant size-class (Fig. 3). Length-frequency distributions of Thysanoessa sp. were significantly different among years (Kolmogorov-Smirnov, all $\mathrm{p}<0.05)$. The small size-class was found in 1995 and 1997, where they accounted for 19 and $8 \%$ of the total number of Thysanoessa sp., respectively, but they were absent from the samples collected in 1996 (Fig. 3). Overall, individuals of the large-size class had slightly different total lengths among years (14.5 \pm $1.7 \mathrm{~mm}, \mathrm{n}=699,14.7 \pm 1.8 \mathrm{~mm}, \mathrm{n}=759$, and $16.5 \pm$ $2.3 \mathrm{~mm}, \mathrm{n}=867$, in 1995, 1996 and 1997, respectively, $F_{2,2322}=232.86, \mathrm{p}<0.0001$ ) (Fig. 3).

The second main prey, Calanoides acutus, prevailed by number and by mass in $19 \%(n=16)$ and $6 \%(n=5)$ of the samples, respectively. It accounted for 18 and $14 \%$ of the diet by reconstituted mass in 1995 and 1997, respectively, but was a rare prey item in 1996 (<1\% by mass) (Fig. 2). Length of $C$. acutus varied significantly between years $\left(F_{2,767}=49.67\right.$, p $<0.0001$, post hoc Tukey HSD multiple comparison test, all p < $0.0001)$, but the differences in length were small (4.1 \pm $0.3 \mathrm{~mm}, \mathrm{n}=338,3.8 \pm 0.2 \mathrm{~mm}, \mathrm{n}=69$, and $4.0 \pm 0.3 \mathrm{~mm}$, $\mathrm{n}=363$, in 1995, 1996 and 1997, respectively). Only Copepodites V and VI were found after examination of a small number of individuals with a large majority of CV over adult copepods.

\section{Maximum dive depths}

Of 139 recorders that were attached, 92 (66\%) were recovered and 87 (63\%) gave reliable measurements (Table 4). All the recorders were recovered within $6 \mathrm{~d}$ after the birds had been equipped, and $23 \%$ were recovered after $1 \mathrm{~d}$ only. The maximum dive depths reached by Pelecanoides georgicus ranged from 15 to $40 \mathrm{~m}$ and averaged $26 \mathrm{~m}$. The frequency distribution of depths was unimodal, with a mode at 20 to $25 \mathrm{~m}$ (Fig. 4). Mean maximum dive depths did not vary significantly among the 3 seasons (Table 4 ).

\section{Stable isotopes}

A brief examination showed the predominance by mass of Thysanoessa sp. in the dietary samples collected for isotopic analyses. Food of Pelecanoides geor-

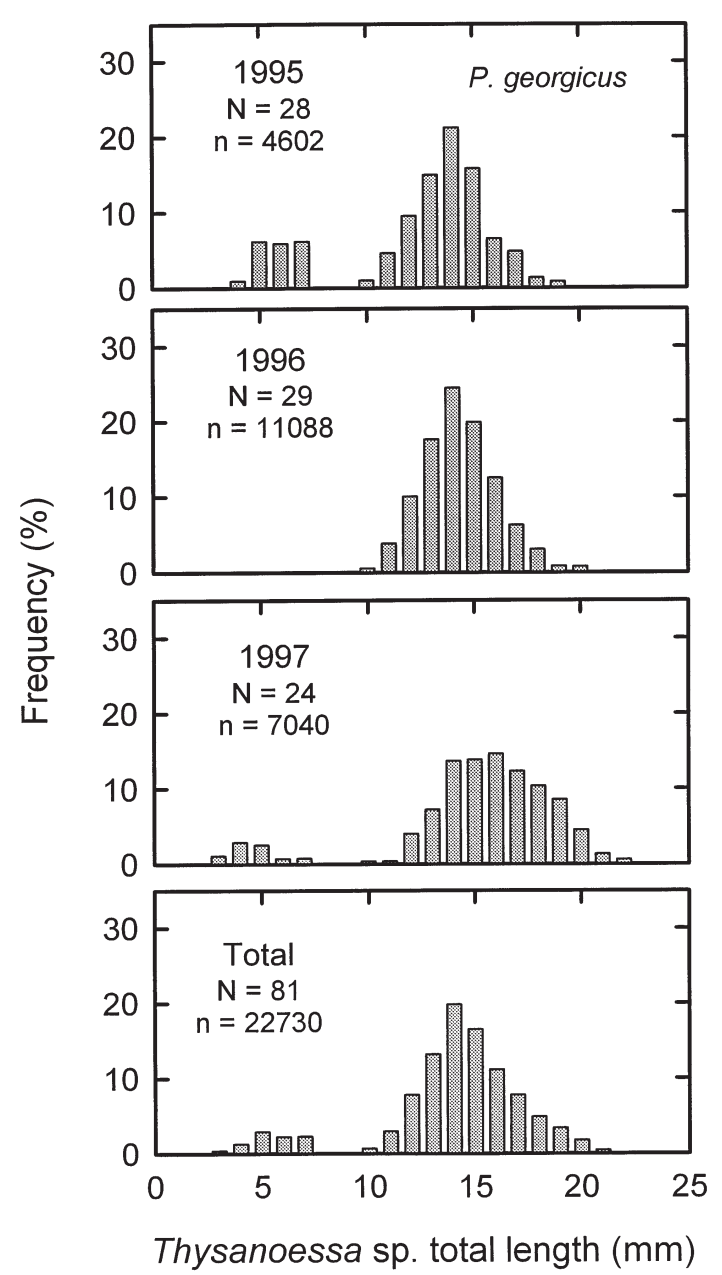

Fig. 3. Pelecanoides georgicus. Length-frequency distribution of the euphausiid Thysanoessa sp. in the diet of $P$. georgicus during 3 consecutive chick-rearing periods $(\mathrm{N}$ : number of food samples; n: number of individuals)

gicus and feathers from chicks and adults were segregated by their stable isotope values (MANOVA, Wilk's Lambda, $F_{4,52}=29.93, \mathrm{p}<0.0001$ ) (Table 5). No significant differences were found among groups in $\delta^{13} \mathrm{C}$ values $\left(F_{2,27}=1.23, \mathrm{p}=0.307\right)$. However, $\delta^{15} \mathrm{~N}$ values were, overall, different $\left(F_{2,27}=125.66, \mathrm{p}<0.0001\right)$, nitrogen stable-isotope ratios of chick food being lower than the ratios in chick and adult feathers (post hoc Tukey HSD multiple comparison test, all $\mathrm{p}<0.0001$ ).

\section{Pelecanoides urinatrix}

Food mass and feeding frequency

Chicks of Pelecanoides urinatrix were fed by the adults on $97 \%$ of the nights, with no significant differences among the 3 seasons. When fed, chicks received 
Table 4. Pelecanoides spp. Comparison of mean maximum dive depths during 3 consecutive chick-rearing periods. Values are means \pm SD with ranges in parentheses

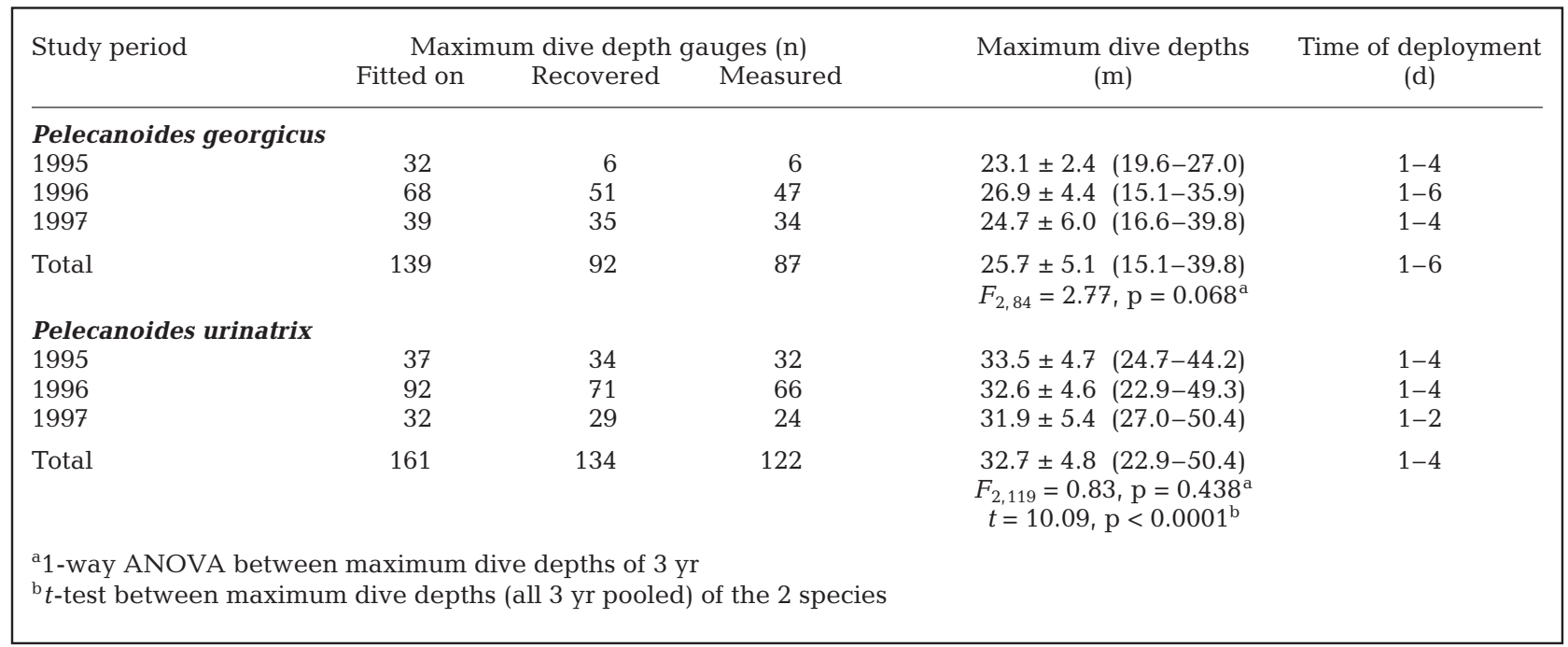

on average $31 \mathrm{~g}$ of food per night, with significant interannual differences (Table 1). Food mass was on average greater in February 1996 than in 1995 and 1997 (post hoc Tukey HSD multiple comparison test, $\mathrm{p}<0.0001)$. The overall mass gain of chicks was $22 \pm$ $25 \mathrm{~g}$ in 11 to $12 \mathrm{~d}$, with significant differences among years $(15 \pm 27,35 \pm 18$ and $14 \pm 24 \mathrm{~g}$, for 1995, 1996 and 1997, respectively, $\left.F_{2,64}=7.18, \mathrm{p}=0.002\right)$. The increase in chick mass was greater in 1996 than in 1995 and

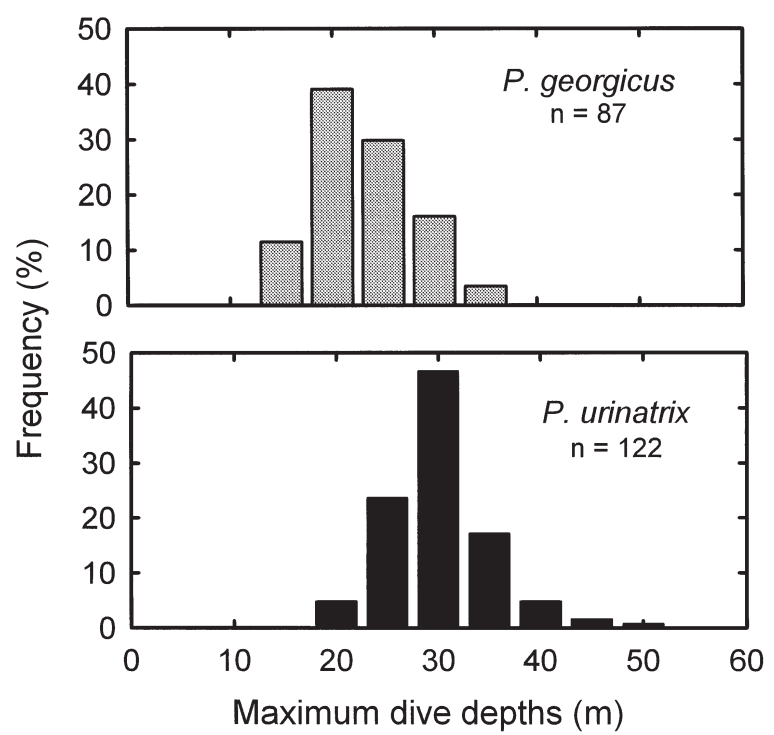

Fig. 4. Pelecanoides spp. Frequency distribution of maximum dive depths during the chick-rearing period (all the $3 \mathrm{yr}$ pooled)
1997 (post Hoc Tukey HSD multiple comparison test, all $\mathrm{p}<0.05)$.

The mean adult body mass (before stomach lavage) of Pelecanoides urinatrix was $154 \mathrm{~g}$, and it differed significantly among seasons $\left(F_{2,106}=4.85, \mathrm{p}=0.010\right)$, birds being heavier in 1995 when compared to 1996 but not to 1997 (post hoc Tukey HSD multiple comparison test, $\mathrm{p}=0.020$ and 0.057 , respectively). The wet mass of the 81 food samples averaged $12 \mathrm{~g}$, with overall significant differences between years $\left(F_{2,78}=8.81\right.$, $\mathrm{p}<0.0001$ ), food samples collected in 1995 being heavier than those collected in 1996 and 1997 (post hoc Tukey HSD multiple comparison test, $\mathrm{p}<0.05$ ) (Table 2).

\section{Diet}

Pelecanoides urinatrix fed exclusively on crustaceans, only 1 fish was found in the 81 stomach contents (Table 6). A total of 58854 prey items, including 7 species of crustaceans, was recovered from the 81 samples (Table 6). The diet was dominated by the hyperiid amphipod Themisto gaudichaudii, which occurred in all the samples and accounted for $61 \%$ of the total number of prey and an estimated $91 \%$ of the food by reconstituted mass. The large carnivorous copepod Paraeuchaeta antarctica ranked second (21\% by number and $9 \%$ by mass), with other common but minor items being zoeal larvae of the crab Halicarcinus planatus (which dominated by number in 4 samples), and the copepods Drepanopus pectinatus (which dominated by number in 2 samples) and Calanus simil- 
Table 5. Pelecanoides spp. Stable-carbon and-nitrogen isotope concentrations (mean $\pm \mathrm{SD} \%$ ) in dietary samples and in feathers of breeding adults and chicks at Kerguelen Islands, and results of 1-way ANOVA for differences among groups for each isotope. Values in the same column not sharing a common superscript letter are significantly different (post hoc Tukey HSD multiple comparison test, $\mathrm{p}<0.05$ )

\begin{tabular}{|lccr|}
\hline Sampling group & Samples $(\mathrm{n})$ & $\delta^{13} \mathrm{C}$ & $\delta^{15} \mathrm{~N}$ \\
\hline Pelecanoides georgicus & & & \\
Food & 9 & $-21.8 \pm 1.0^{\mathrm{a}}$ & $5.0 \pm 0.8^{\mathrm{a}}$ \\
Chick feathers & 10 & $-21.1 \pm 0.4^{\mathrm{a}}$ & $8.9 \pm 0.4^{\mathrm{b}}$ \\
Adult feathers & 11 & $-21.5 \pm 1.4^{\mathrm{a}}$ & $9.3 \pm 0.7^{\mathrm{b}}$ \\
Pelecanoides urinatrix & & & \\
Food & 10 & $-19.1 \pm 0.3^{\mathrm{a}}$ & $8.0 \pm 0.7^{\mathrm{b}}$ \\
Chick feathers & 10 & $-19.5 \pm 2.7^{\mathrm{a}}$ & $10.9 \pm 1.7^{\mathrm{c}}$ \\
Adult feathers & 10 & $-21.5 \pm 3.8^{\mathrm{a}}$ & $9.4 \pm 1.6^{\mathrm{b}}$ \\
ANOVA & & $F_{5,54}=3.13$ & $F_{5,54}=30.71$ \\
& & $\mathrm{p}=0.015$ & $\mathrm{p}<0.0001$ \\
\hline
\end{tabular}

Maximum dive depths

Of 161 recorders that were attached, $134(83 \%)$ were recovered and 122 $(76 \%)$ gave reliable measurements (Table 4). All the recorders were recovered within $4 \mathrm{~d}$ after the birds had been equipped, and $69 \%$ were recovered after $1 \mathrm{~d}$ only. The maximum dive depths reached by Pelecanoides urinatrix ranged from 23 to $50 \mathrm{~m}$, and averaged $33 \mathrm{~m}$. The frequency distribution of depths was unimodal, with a mode at 30 to $35 \mathrm{~m}$ (Fig. 4). Mean maximum dive depths did not vary significantly among the 3 seasons (Table 4). limus. Rare to very rare prey items included 2 other crustacean species (Table 6).

Themisto gaudichaudii predominated by number and by mass in $80 \%(n=65)$ and $95 \%(n=77)$ of the samples, respectively. It was the dominant prey every season, accounting for an estimated $73 \%$ to $99 \%$ of the diet by reconstituted mass (Fig. 2). Only 1 size-class of T. gaudichaudii was important in the diet of $P$. urinatrix, with a mode at 15 to $16 \mathrm{~mm}$ TL (Fig. 5). A few small individuals (TL $<10 \mathrm{~mm}$ ) were present in 1995 and 1997, but they were nearly absent in 1996. Overall, total length of T. gaudichaudii varied slightly but significantly among the 3 seasons $(15.4 \pm 1.9 \mathrm{~mm}, \mathrm{n}=$ $1319,15.2 \pm 1.7 \mathrm{~mm}, \mathrm{n}=1320$, and $14.8 \pm 2.1 \mathrm{~mm}, \mathrm{n}=$ 976, in 1995, 1996 and 1997, respectively, $F_{2,3612}=$ $35.82, \mathrm{p}<0.0001)$. Length-frequency distributions differed also over the 3 yr (Kolmogorov-Smirnov, all p < 0.0001).

The second main prey, Paraeuchaeta antarctica, predominated numerically and by mass in $12 \%(\mathrm{n}=10)$ and $5 \%(n=4)$ of the samples, respectively. It accounted for 8 and $26 \%$ of the diet by the estimated reconstituted masses in 1996 and 1997, respectively, but was a rare prey item in 1995 (<1\% by mass) (Fig. 2). CV dominated over CVI in the diet (68 vs $32 \%$, Pearson chi-squared test, $\left.\chi^{2}{ }_{1}=1675.34, \mathrm{p}<0.0001\right)$, with CIV present in negligible numbers (Table 7 ). The proportions of female and male $P$. antarctica were slightly but significantly different in CV (48 and 52\%, respectively, $\chi^{2}{ }_{1}=8.57, \mathrm{p}=$ $0.003)$, while they were highly biased in favour of females in CVI (98 and $2 \%, \chi^{2}{ }_{1}=3737.98, p<0.0001$ ). Overall, the proportions of females CV and CVI and males CV and CVI varied significantly over the 3 yr $\left(\chi^{2}{ }_{6}\right.$ = 285.08, $\mathrm{p}<0.0001)$, fewer females CV and more females CVI being found in 1997 when compared to 1995 and 1996 (Table 7).

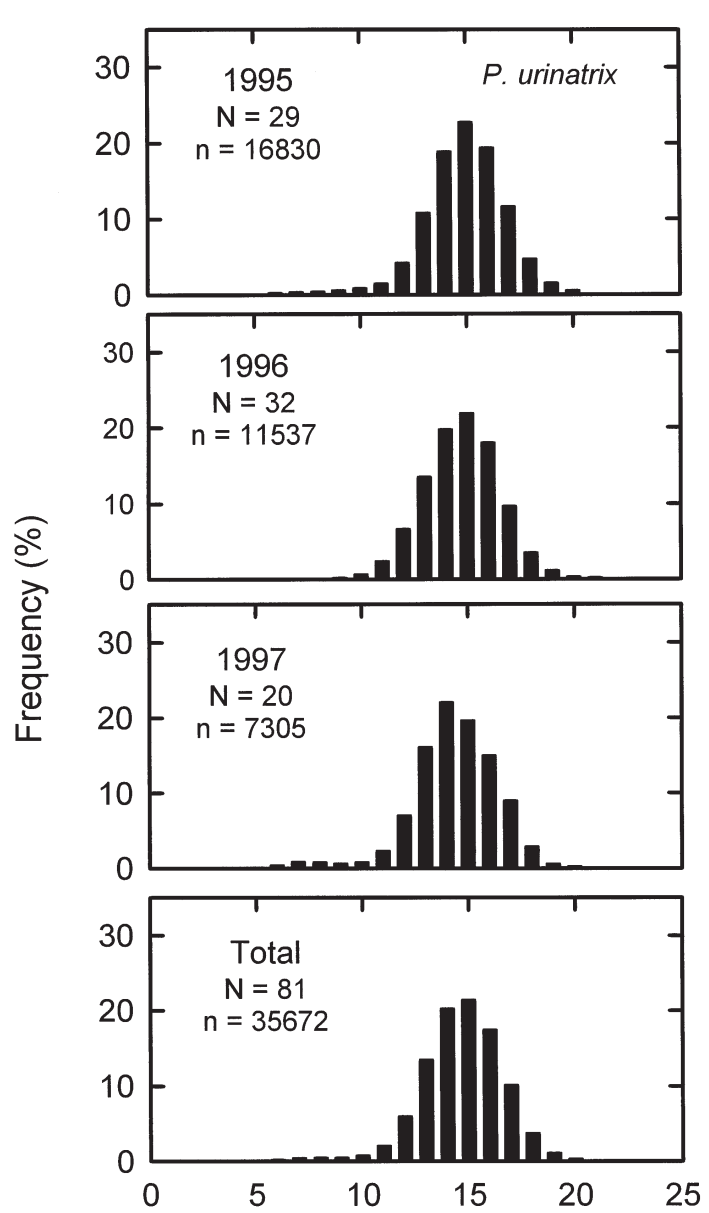

Themisto gaudichaudii total length $(\mathrm{mm})$

Fig. 5. Pelecanoides urinatrix. Length-frequency distribution of the hyperiid Themisto gaudichaudii in the diet of P. urinatrix during 3 consecutive chick-rearing periods ( $\mathrm{N}$ : number of food samples; n: number of individuals) 
Table 6. Pelecanoides urinatrix. Frequency of occurrence, number, reconstituted mass and length of prey items recovered from stomach contents of $P$. urinatrix during chick-rearing (total for all 81 samples pooled)

\begin{tabular}{|c|c|c|c|c|c|c|c|c|c|}
\hline \multirow[t]{2}{*}{ Prey species } & \multicolumn{2}{|c|}{$\begin{array}{l}\text { Occurrence } \\
\text { in stomachs }\end{array}$} & \multicolumn{2}{|c|}{ Number } & \multicolumn{2}{|c|}{$\begin{array}{l}\text { Reconstituted } \\
\text { mass }\end{array}$} & \multicolumn{3}{|c|}{$\begin{array}{l}\text { Body length } \\
\text { (mm) }\end{array}$} \\
\hline & (n) & $(\%)$ & (n) & $(\%)$ & $(g)$ & $(\%)$ & Mean & Range & (n) \\
\hline Crustaceans & 81 & 100.0 & 58853 & 100.0 & 1622.9 & 100.0 & & & \\
\hline \multicolumn{10}{|l|}{ Euphausiacea } \\
\hline Euphausia sp. & 1 & 1.2 & 1 & $<0.1$ & $<0.1$ & $<0.1$ & & & \\
\hline \multicolumn{10}{|l|}{ Decapoda } \\
\hline Halicarcinus planatus (zoeal larvae) & 19 & 23.5 & 6734 & 11.4 & 3.4 & 0.2 & $2.9 \pm 0.2$ & $2.4-3.3$ & 38 \\
\hline \multicolumn{10}{|l|}{ Mysida } \\
\hline Mysidetes morbihanensis & 3 & 3.7 & 11 & $<0.1$ & 0.1 & $<0.1$ & $23.7 \pm 3.0$ & $19.5-24.4$ & 7 \\
\hline \multicolumn{10}{|l|}{ Amphipoda } \\
\hline Themisto gaudichaudii & 81 & 100.0 & 35672 & 60.6 & 1471.7 & 90.7 & $15.2 \pm 1.9$ & $4.4-23.2$ & 3615 \\
\hline \multicolumn{10}{|l|}{ Copepoda } \\
\hline Calanus simillimus & 16 & 19.8 & 1490 & 2.5 & 1.9 & 0.1 & $3.2 \pm 0.3$ & $2.6-3.7$ & 84 \\
\hline Calanoides acutus & 4 & 4.9 & 68 & 0.1 & 0.1 & $<0.1$ & $3.9 \pm 0.2$ & $3.7-4.4$ & 14 \\
\hline Drepanopus pectinatus & 37 & 45.7 & 2170 & 3.7 & 0.5 & $<0.1$ & $2.3 \pm 0.2$ & $1.2-2.7$ & 169 \\
\hline Paraeuchaeta antarctica & 51 & 63.0 & 12564 & 21.3 & 144.9 & 8.9 & $7.1 \pm 1.2$ & $6.1-8.7$ & $9278^{\mathrm{a}}$ \\
\hline Unidentified copepods & 18 & 22.2 & 143 & 0.2 & 0.2 & $<0.1$ & & & \\
\hline Fish & 1 & 1.2 & 1 & $<0.1$ & 0.1 & $<0.1$ & & & \\
\hline Unidentified fish & 1 & 1.2 & 1 & $<0.1$ & 0.1 & $<0.1$ & & & \\
\hline Total & & & 58854 & 100.0 & 1623.0 & 100.0 & & & \\
\hline
\end{tabular}

Table 7. Pelecanoides urinatrix. Percentage composition of developmental stages of Paraeuchaeta antarctica in the diet of $P$. urinatrix during 3 consecutive chick-rearing periods

\begin{tabular}{|lcccccc|}
\hline \multirow{2}{*}{ Study period } & \multirow{2}{*}{$\begin{array}{c}\text { Samples } \\
\text { (n) }\end{array}$} & \multicolumn{2}{c}{ Copepodite IV (\%) } & \multicolumn{2}{c|}{ Copepodite V (\%) } & \multicolumn{2}{c|}{ Copepodite VI (\%) } \\
& \multicolumn{2}{c}{ Female } & Male & Female & Male & Female \\
\hline 1995 & 681 & 0.1 & 0.0 & 38.0 & 38.5 & 23.2 \\
1996 & 4269 & 0.0 & 0.0 & 39.4 & 37.1 & 0.1 \\
1997 & 7614 & $<0.1$ & $<0.1$ & 29.0 & 33.8 & 36.5 \\
Total & 12564 & $<0.1$ & $<0.1$ & 33.0 & 35.2 & 0.4 \\
& & & & & & \\
\hline
\end{tabular}

\section{Stable isotopes}

A brief examination showed the predominance by mass of Themisto gaudichaudii in the dietary samples collected for isotopic analyses, 2 of them also containing a significant amount of Paraeuchaeta antarctica. Food of Pelecanoides urinatrix and feathers from chicks and adults were segregated by their stableisotope values (MANOVA, Wilk's Lambda, $F_{4,52}=$ 11.04, $\mathrm{p}<0.0001$ ) (Table 5). No significant differences were found among chick food and chick and adult feathers in $\delta^{13} \mathrm{C}$ values $\left(F_{2,27}=2.28, \mathrm{p}=0.121\right)$. However, $\delta^{15} \mathrm{~N}$ values were, overall, different $\left(F_{2,27}=\right.$ 10.78, p $<0.0001)$, with chick feathers having higher $\delta^{15} \mathrm{~N}$ values than chick food (post hoc Tukey HSD multiple comparison test, $\mathrm{p}<0.0001$ ) and adult feathers $(p=0.049)$.

\section{DISCUSSION}

A complete dietary segregation was found at the Iles Kerguelen between the 2 sympatric and closely related species Pelecanoides georgicus and P. urinatrix during the breeding period. During chick-rearing, P. georgicus rely almost exclusively on the euphausiid Thysanoessa sp. and the copepod Calanoides acutus for foods both of which are taken in offshore waters, while $P$. urinatrix prey mainly upon the hyperiid amphipod Themisto gaudichaudii and the copepod Paraeuchaeta antarctica in the close vicinity of the colonies. The stable-carbon and -nitrogen isotopic compositions of adult feathers were, however, identical in both species, indicating no trophic segregation during the moulting (inter-breeding) period when birds are not constrained to return to the colonies, and feed in offshore waters. 


\section{Pelecanoides georgicus}

At the Iles Kerguelen, Pelecanoides georgicus is mainly a macrozooplankton feeder, with postlarval fish only a minor component of its food. This is consistent with previous studies at South Georgia (Reid et al. 1997) and Iles Crozet (Ridoux 1994). Hyperiid amphipods, euphausiids and copepods are the main food items, with high variations in the numbers and masses of the main prey species among the 3 study areas (Table 8). At the southernmost locality, south of the Antarctic Polar Front (South Georgia), copepods dominate numerically with 2 species involved (Calanoides acutus and Calanus propinquus), but, owing to their larger size, euphausiids (mainly Euphausia superba) are the main items by mass (Reid et al. 1997). North of the Antarctic Polar Front (Iles Crozet), euphausiids form the bulk of the food, Thysanoessa sp. and the subantarctic krill E. vallentini ranking, respectively, first and second both numerically and by mass (Ridoux 1994). At the Iles Kerguelen, which are located in the immediate vicinity of the Antarctic Polar Front (Park et al. 1993), the diet includes 2 important prey species, Thysanoessa sp. and Calanoides acutus (Table 3). Taken together, these data suggest that $P$. georgicus is an opportunist feeder that preys upon the most available swarming crustaceans found in its foraging ground during the breeding season. Dietary investigations among several years at South Georgia (Payne \& Prince 1979, Reid et al. 1997) and the Kerguelen Islands (present study) showed no large interannual differences in the main prey species at a given locality, thus indicating that $P$. georgicus feeds on predictable marine resources from 1 breeding period to the next at a given locality.

Thysanoessa sp. was consistently the main prey item over the $3 \mathrm{yr}$ of the study period, thus emphasising the importance of that euphausiid in the diet of Pelecanoides georgicus at Iles Kerguelen during the breeding season. The highly digested condition of the stomach contents precluded the identification of individuals of the genus Thysanoessa to the species level. Two species of that genus, the closely related $T$. vicina and T. macrura, occur in the vicinity of the Antarctic Polar Front and in Antarctic waters, including the Kerguelen region (Lomakina 1966, Pakhomov 1993). The fact that $P$. georgicus fed upon 2 well-defined size-classes of Thysanoessa sp. suggests either that each size-class belonged to a different Thysanoessa species, or, alternatively, that the birds preyed upon 2 size-classes of the same species.

During the chick-rearing period, maximum depth gauges indicated that Pelecanoides georgicus foraged in the top $40 \mathrm{~m}$ of the water at Iles Kerguelen, with a mean of $26 \mathrm{~m}$ and a modal class of 20 to $25 \mathrm{~m}$. This is in agreement with preliminary work performed at South Georgia, where the maximum dive depths of 6 birds averaged $26 \mathrm{~m}$ (Prince \& Jones 1992). No interannual variations were recorded in the maximum dive depths reached by the petrels at Iles Kerguelen, suggesting that swarms of Thysanoessa sp. and Calanoides acutus were consistently located in the sub-surface during the 3 seasons.

Table 8. Pelecanoides spp. Proportions by number of the main prey species ( $\geq 10 \%$ ) at different breeding localities. Data from Reid et al. (1997) for South Georgia, Ridoux (1994) for Crozet, and the present study for Kerguelen

\begin{tabular}{|c|c|c|c|c|c|c|}
\hline \multirow[b]{2}{*}{ Species } & \multicolumn{3}{|c|}{ Pelecanoides georgicus } & \multicolumn{3}{|c|}{ Pelecanoides urinatrix } \\
\hline & $\begin{array}{l}\text { South Georgia } \\
\quad(\mathrm{n}=95)\end{array}$ & $\begin{array}{l}\text { Crozet } \\
(\mathrm{n}=23)\end{array}$ & $\begin{array}{l}\text { Kerguelen } \\
(\mathrm{n}=83)\end{array}$ & $\begin{array}{l}\text { South Georgia } \\
\quad(\mathrm{n}=43)\end{array}$ & $\begin{array}{l}\text { Crozet } \\
(\mathrm{n}=21)\end{array}$ & $\begin{array}{c}\text { Kerguelen } \\
(\mathrm{n}=81)\end{array}$ \\
\hline Amphipoda & $<1$ & 7 & 3 & 1 & 29 & 61 \\
\hline Themisto gaudichaudii & $<1$ & $<1$ & 2 & 1 & 17 & 61 \\
\hline Primno macropa & $<1$ & 6 & 1 & - & 12 & - \\
\hline Euphausiacea & 11 & 93 & 50 & 3 & 66 & $<1$ \\
\hline Euphausia vallentini & - & 22 & $<1$ & - & 59 & - \\
\hline Euphausia superba & 10 & - & - & 2 & - & - \\
\hline Thysanoessa sp. & 1 & 70 & 50 & 1 & 7 & - \\
\hline Reptantia & - & - & - & - & - & 11 \\
\hline Halicarcinus planatus (zoeal larvae) & - & - & - & - & - & 11 \\
\hline Copepoda & 89 & $<1$ & 46 & 97 & 3 & 28 \\
\hline Calanus propinquus & 12 & - & - & 11 & - & - \\
\hline Calanoides acutus & 44 & _- & 44 & 27 & - & $<1$ \\
\hline Rhincalanus gigas & 3 & - & 2 & 13 & - & - \\
\hline Euchaetidae $^{\mathrm{a}}$ & - & _- & $<1$ & 4 & $<1$ & 21 \\
\hline Unidentified copepods & 29 & $<1$ & $<1$ & 40 & 3 & - \\
\hline
\end{tabular}


Isotopic signatures of chick feathers of Pelecanoides georgicus show an enrichment relative to food, amounting to a non-significant $0.7 \%$ for $\delta^{13} \mathrm{C}$ and a highly significant $3.9 \%$ for $\delta^{15} \mathrm{~N}$ (Table 5). These values are within the range of those $\left(-0.4\right.$ to $4.4 \%$ for $\delta^{13} \mathrm{C}$ and 1.1 to $5.6 \%$ o for $\delta^{15} \mathrm{~N}$ ) obtained from feathers of various species of birds (Mizutani et al. 1990, 1992, Hobson \& Clark 1992a,b, Thompson \& Furness 1995, Cherel et al. 2000). Interestingly, feathers from chicks and adults of $P$. georgicus had similar isotopic signatures. Identical values in both $\delta^{13} \mathrm{C}$ and $\delta^{15} \mathrm{~N}$ strongly suggest no major changes in the trophic positions and feeding ecology of the birds between the moulting period of the chicks (breeding period) and the moulting period of adults (inter-breeding period). Adults from Kerguelen, thus, feed at the same trophic level and in the same broad foraging area all year long.

\section{Pelecanoides urinatrix}

At Iles Kerguelen, as at Iles Crozet (Ridoux 1994), Pelecanoides urinatrix feeds on macrozooplankton only, while at South Georgia an indeterminate proportion of fish was found in a majority of dietary samples (Reid et al. 1997). As with its relative P. georgicus, hyperiid amphipods, euphausiids and copepods are the main food items everywhere, with large variations in the number and mass of the main prey species among the study areas (Table 8). Copepods (including Calanoides acutus, Rhincalanus gigas and Calanus propinquus) and Euphausia superba dominated the diet at South Georgia (Reid et al. 1997), while at Iles Crozet copepods were negligible, the main prey species being $E$. vallentini together with 2 species of hyperiids, Themisto gaudichaudii and Primno macropa (Ridoux 1994). Two species formed the bulk of the food at Iles Kerguelen, T. gaudichaudii and the copepod Paraeuchaeta antarctica, the latter being found previously as a minor item only at the 2 other localities so far investigated. Overall, these data suggest that $P$. urinatrix, like $P$. georgicus, is an opportunist feeder, differences in species composition reflecting the local availability of marine resources which are probably predictable in time and space at a given locality, since no major changes occurred over the 3 seasons at Iles Kerguelen. Consistency over the study period was also found in the size-class and developmental stages of $T$. gaudichaudii and Paraeuchaeta antarctica, respectively, diving petrels feeding almost exclusively on adults of the former species, and on $\mathrm{CV}$ and adult females (CVI) of the latter one. Stomach contents collected during the summer months, including February, showed no short-term changes in the main prey items of $P$. urinatrix (Bocher et al. 2000). This indicates that the relatively short (11 to $12 \mathrm{~d}$ ) sampling time was representative of the whole breeding period for that species.

High numbers of Pelecanoides urinatrix are often observed feeding during the breeding period inside the sheltered Golfe du Morbihan, where Ile Mayes is located (Weimerskirch et al. 1989, authors' unpubl. data). Both biological surveys and the diet of other diving seabirds feeding there (rockhopper and gentoo penguins) indicated that only a few species of mesoand macrozooplankton are important in the bay, the small and overwhelming herbivorous endemic copepod Drepanopus pectinatus, Euphausia vallentini, and the carnivorous Themisto gaudichaudii and Paraeuchaeta antarctica, Calanus simillimus being less numerous (Bost et al. 1994, Razouls et al. 1996, Tremblay \& Cherel 2000, author's unpubl. data). It should be noted that previous oceanographic samples in the central Golfe du Morbihan did not locate P. antarctica (Razouls et al. 1996), but, following seabird dietary information, it was recently found in high numbers in tows conducted in the western part of the Golfe du Morbihan (S. Razouls \& P. Mayzaud unpubl. data). Thus, both observations at sea and prey items retrieved from the breeding colony indicate that $P$. urinatrix fed there, in coastal waters in close vicinity to their colony. The lack of E. vallentini in the diet of $P$. urinatrix is easily explained by the location of that euphausid near the bottom, at depths too deep for diving petrels but not for penguins (Tremblay \& Cherel 2000). Inshore foraging habits are also indicated by the occurrence in food samples of zoeal larvae of Halicarcinus planatus, and, to a lesser extent of the endemic Mysidetes morbihanensis, which are abundant species in the area (Richer de Forges 1977, Ledoyer 1995).

At Iles Crozet and South Georgia (Bird Island), Pelecanoides urinatrix feed mainly in neritic waters not very far from the colonies during the breeding period (Jouventin et al. 1988, Reid et al. 1997). Unlike at Iles Crozet and Bird Island, the coastline at Iles Kerguelen is dissected by numerous fjords and peninsulas. Birds from the Golfe du Morbihan at Iles Kerguelen have a different feeding ecology than elsewhere, because they forage in a very sheltered coastal environment where they prey on 2 macrozooplankton species that are not the dominant prey items at other localities.

During the chick-rearing period, maximum depth gauges indicated that Pelecanoides urinatrix foraged in the top $50 \mathrm{~m}$ of the water at Iles Kerguelen, with a mean of $33 \mathrm{~m}$ and a mode of 30 to $35 \mathrm{~m}$. This is slightly less than the average value $(39 \mathrm{~m})$ obtained in the same population during the breeding season in 1991/92 (Chastel 1994), but in agreement with the more intensive work conducted over more than 1 yr in 1995/96 (31 m with a mode at 30 to $35 \mathrm{~m}$ ) (Bocher et al. 2000). 
Stable-nitrogen isotope ratios of chick feathers of Pelecanoides urinatrix show an enrichment relative to food amounting $2.9 \%$, with no enrichment in $\delta^{13} \mathrm{C}$ (Table 5). The feathers from chicks and adults had different isotopic signatures, with adult feathers having a non-significant lower value in $\delta^{13} \mathrm{C}$ and a significant lower $\delta^{15} \mathrm{~N}$ value. Since variations in $\delta^{13} \mathrm{C}$ and $\delta^{15} \mathrm{~N}$ values of marine organisms are generally related to a gradient between inshore and offshore organisms, and dietary differences, respectively (Wada et al. 1987, Hobson 1993, Hobson et al. 1994, but see Schell et al. 1998 for discussion of $\delta^{13} \mathrm{C}$ ), such changes indicate adult $P$. urinatrix feeding in more offshore waters at a lower trophic level during moult (inter-breeding period). This is in agreement with the recent finding that shows most breeding adults desert colonies after the fledging period (Bocher et al. 2000). The fact that some $P$. urinatrix are observed all year long near the colonies nevertheless suggests that the offshore foraging grounds are not located very far from Iles Kerguelen.

\section{Dietary segregation}

A major finding of this study is the almost complete dietary segregation of Pelecanoides georgicus and $P$. urinatrix during the chick-rearing period, the former species feeding on Thysanoessa sp. and Calanoides acutus, and the latter species on Themisto gaudichaudii and Paraeuchaeta antarctica (Tables 3 \& 6). As discussed above $P$. urinatrix foraged in the Golfe du Morbihan, where feeding concentrations of $P$. georgicus were not observed (Weimerskirch et al. 1989). Our question then is: where are the foraging grounds of $P$. georgicus located? Oceanographic surveys did not find Thysanoessa sp. or C. acutus in the Golfe du Morbihan (Bost et al. 1994, Razouls et al. 1996), but they were caught in more offshore waters around the archipelago (Pakhomov 1993, Semelkina 1993, Razouls et al. 1998). Moreover, these species, together with Primno macropa and Rhincalanus gigas and other minor prey items are known to be primarily oceanic in their distribution (Lomakina 1966, Pakhomov 1993, Vinogradov et al. 1996, Errhif et al. 1997), T. gaudichaudii occurring everywhere, with more dense concentrations near the Kerguelen coast (Pakhomov 1993). Prey biogeography, therefore, suggests offshore foraging grounds over the slope and adjacent oceanic waters for P. georgicus, contrasting with the coastal feeding habits of $P$. urinatrix.

A spatial segregation at sea during the chick-rearing period is also supported by the digested state of stomach contents, feeding frequency and stable isotopes. Food samples of Pelecanoides georgicus in- cluded only well-digested items, while those of $P$. urinatrix often contained a large number of intact prey. P. georgicus chicks were fed on $81 \%$ of the nights, while those of $P$. urinatrix were visited almost every night (Table 1), thus suggesting closer foraging grounds for the latter species. Note also that for $P$. urinatrix both parents were commonly found together in their burrow at night, while this rarely occurred for $P$. georgicus. Lastly, chick food and feathers of the 2 species of diving petrels were segregated by their stable isotope values (Table 5). The diet and feathers from $P$. urinatrix have higher non-significant $\delta^{13} \mathrm{C}$ and significant $\delta^{15} \mathrm{~N}$ values, and this can be related to more inshore prey and feeding at a higher trophic level, respectively, than $P$. georgicus. This is in agreement with the feeding habits of the diving petrels' prey, Themisto gaudichaudii and Paraeuchaeta antarctica, being carnivorous (Øresland 1991, Pakhomov \& Perissinotto 1996), while Thysanoessa sp. is omnivorous and Calanoides acutus is herbivorous (Graeve et al. 1994, Hagen \& Kattner 1998, Falk-Petersen et al. 1999). Furthermore, isotope signature of feathers integrates trophic information during the moulting period, suggesting, together with the consistency in differences for other dietary parameters over the $3 \mathrm{yr}$ of the study, that the segregation at sea between the 2 species is not an artefact of sampling period or changes in prey availability. Spatial segregation at sea of diving petrels during the breeding period can be interpreted as a mechanism to avoid inter-specific competition for marine resources in a relatively limited coastal area (Golfe du Morbihan) when the birds are central place foragers.

Spatial segregation at sea, but overlap in the main prey items, was found at Iles Crozet during the breeding season, with Pelecanoides urinatrix foraging mainly in neritic waters and $P$. georgicus in slope waters (Jouventin et al. 1988, Ridoux 1994). It was difficult to compare our data on feeding frequency and food mass of chicks with those previously collected at Iles Crozet and South Georgia (Payne \& Prince 1979, Jouventin et al. 1985, Roby 1989) due to differences in methods among the 3 studies. In agreement with the results from Kerguelen, feeding frequency of $P$. georgicus was nevertheless lower at Iles Crozet, while it was almost identical for the 2 species at South Georgia, suggesting a greater overlap in the foraging grounds at the latter locality than in the southern Indian Ocean. The present study is the first to investigate feeding frequency and food mass of chicks over several years, and it shows no large interannual differences in those parameters, except for the higher food mass and, accordingly, better chick growth of $P$. urinatrix chicks in 1996 (Table 1), suggesting better conditions in the Golfe du Morbihan during that year. 
Maximum depth gauges indicate a vertical segregation at sea between the 2 species, Pelecanoides georgicus reaching on average shallower depths (mode at 20 to $25 \mathrm{~m}$ ) than $P$. urinatrix (mode at 30 to $35 \mathrm{~m}$ ) (Fig. 4). Such differences occurred every year (Table 4), and were also found when comparing values obtained for the 2 species at the same time in January 1995 and $1996\left(t_{24}=3.72, \mathrm{p}=0.001\right.$, and $t_{69}=4.27, \mathrm{p}<0.0001$, for 1995 and 1996, respectively; data from Bocher et al. 2000 and the present study), indicating that the vertical foraging segregation is not an artefact of sampling period. Though the maximum dive depth gauge method only indicated the deepest dive on a given foraging trip, which probably differs considerably from the average depth of dives, it has given a first insight into the diving capabilities of petrels, confirming the hypothesis of Reid et al. (1997) that $P$. urinatrix is a deeper diver than $P$. georgicus.

Unlike chick feathers, adult feathers of the 2 species of diving petrels were not segregated by their stable isotope values (Table 5), strongly suggesting no dietary segregation during the moulting (inter-breeding) period, when birds are self-centred foragers. This implies no major changes in the food and feeding ecology of Pelecanoides georgicus because adults and chick feathers have identical $\delta^{13} \mathrm{C}$ and $\delta^{15} \mathrm{~N}$ values, but a considerable change for $P$. urinatrix for which adult and chick feathers were segregated by their isotopic signatures. Adults of $P$. urinatrix therefore shifts from coastal to more offshore foraging grounds where they feed at a lower trophic level (identical to that of $P$. georgicus) during moult. Lack of dietary segregation during the inter-breeding period is not in agreement with more sedentary habits in $P$. georgicus than in $P$. urinatrix at that time, as discussed by Stahl et al. (in press). $\delta^{13} \mathrm{C}$ values of feathers of adult diving petrels are identical to those in feathers of $P$. georgicus chicks, but lower than those in feathers of adult black-browed albatrosses (Diomedea melanophrys), which are known to moult north of the Subtropical Front (Cherel et al. 2000). Taken together these data suggest no major latitudinal migrations of diving petrels during moult, birds remaining south of 40 to $45^{\circ} \mathrm{S}$, a belt which is marked by a strong gradient of $\delta^{13} \mathrm{C}$ in marine surface waters (François et al. 1993).

The genus Pelecanoides comprises 4 species, including the poorly known $P$. magellani and the Peruvian diving petrel $P$. garnotii. Maximum dive depth of $P$. garnotii averaged $32 \mathrm{~m}$, with birds feeding on planktonic crustaceans (Euphausia mucronata and the squat lobster Pleuroncodes monodon), which dominated numerically, and fish (larval stages and Normanichthys crockeri), which accounted for $52 \%$ by mass of the diet (Zavalaga \& Jahncke 1997, Jahncke et al. 1999). Both the food and diving capabilities of $P$. gar- notii are thus similar to those of $P$. georgicus and $P$. urinatrix, the only significant difference being the relative importance of fish in its diet.

Among the seabird community from Iles Crozet, diving petrels belong to the group of small surface feeders and pelagic divers characterised by macrozooplanktonic and micronektonic prey taxa. The 2 species show highest dietary overlap indices both with most small surface feeders and crested penguins (Eudyptes spp.) (Ridoux 1994). Such characteristics are likely to occur at Iles Kerguelen too, but the paucity of information on seabirds there precludes investigation of dietary relationships within the community. Diving capabilities of diving petrels are better than those of small surface feeders (Chastel \& Bried 1996) but poorer than those of crested penguins (Green et al. 1998, Cherel et al. 1999). $P$. georgicus and $P$. urinatrix thus share a unique vertical niche in the water column within the community, the 2 species segregating horizontally during the breeding period, but probably not during moult.

Acknowledgements. The authors thank C. Trouvé and G. Parry for their help in analysis of dietary samples and stable isotopes, respectively, S. Razouls for her help in copepod determination, and J. Bried, O. Duriez, G. Fradet, F. Jiguet, G. Juin, B. Labidoire and T. Mougey for their work in the field. Analysis of the data was supported financially by a grant des Conseils Généraux des Deux-Sèvres et de la Charente Maritime, and by a grant from the Groupement de Recherche en Environnement 1069 'Ecosystèmes Polaires et Anthropisation' (directed by Pierre Jouventin), from the C.N.R.S. Programme IOZ: Interactions Oiseaux-Zooplancton. Field work was supported financially and logistically by the Institut Français pour la Recherche et la Technologie Polaires (IFRTP, Programme No. 109), and the Terres Australes et Antarctiques Françaises.

\section{LITERATURE CITED}

Baker A de C, Boden BP, Brinton E (1990) A practical guide to the euphausiids of the world. Natural History Museum Publications, London

Bocher P, Labidoire B, Cherel Y (2000) Maximum dive depths of common diving petrels (Pelecanoides urinatrix) during the annual cycle at Mayes Island, Kerguelen. J Zool (Lond) 251:517-524

Boschi EE, Scelzo MA, Goldstein B (1969) Desarrollo larval del cangrejo, Halicarcinus planatus (Fabricius) (Crustacea, Decapoda, Hymenosomidae), en el laboratorio, con observaciones sobre la distribucion de la especie. Bull Mar Sci 19:225-242

Bost CA, Koubbi P, Genevois F, Ruchon L, Ridoux V (1994) Gentoo penguin Pygoscelis papua diet as an indicator of planktonic availability. Polar Biol 14:147-153

Burger AE, Wilson RP (1988) Capillary-tube depth gauges for diving animals: an assessment of their accuracy and applicability. J Field Ornithol 59:345-354

Chastel O (1994) Maximum diving depths of common diving petrels Pelecanoides urinatrix at Kerguelen Islands. Polar Biol 14:211-213 
Chastel O, Bried J (1996) Diving ability of blue petrels and thin-billed prions. Condor 98:627-629

Chaurand T, Weimerskirch H (1994) The regular alternation of short and long foraging trips in the blue petrel (Halobaena caerulea): a previously undescribed strategy of food provisioning in a pelagic seabird. J Anim Ecol 63: 275-282

Cherel Y, Tremblay Y, Guinard E, Georges JY (1999) Diving behaviour of female northern rockhopper penguins, Eudyptes chrysocome moseleyi, during the brooding period at Amsterdam Island (Southern Indian Ocean). Mar Biol 134:375-385

Cherel Y, Hobson KA, Weimerskirch H (2000) Using stableisotope analysis of feathers to distinguish moulting and breeding origins of seabirds. Oecologia 122:155-162

Croxall JP, Prince PA (1980) Food, feeding ecology and ecological segregation of seabirds at South Georgia. Biol J Linn Soc 14:103-131

Croxall JP, Prince PA, Hunter I, McInnes SJ, Copestake PG (1984) The seabirds of the Antarctic Peninsula, islands of the Scotia Sea, and Antarctic Continent between $80^{\circ} \mathrm{W}$ and $20^{\circ} \mathrm{W}$ : their status and conservation. In: Croxall JP, Evans PGH, Schreiber RW (eds) Status and conservation of the World's seabirds. ICBP Tech Publ 2:637-666

Errhif A, Razouls C, Mayzaud P (1997) Composition and community structure of pelagic copepods in the Indian sector of the Antarctic Ocean during the end of the austral summer. Polar Biol 17:418-430

Falk-Petersen S, Sargent JR, Lønne OJ, Timofeev S (1999) Functional biodiversity of lipids in Antarctic zooplankton: Calanoides acutus, Calanus propinquus, Thysanoessa macrura and Euphausia crystallorophias. Polar Biol 21: $37-47$

François R, Altabet MA, Goericke R, McCorkle DC, Brunet C, Poisson A (1993) Changes in the $\delta^{13} \mathrm{C}$ of surface water particulate organic matter across the Subtropical Convergence in the SW Indian Ocean. Global Biogeochem Cycles $7: 627-644$

Graeve M, Hagen W, Kattner G (1994) Herbivorous or omnivorous? On the significance of lipid compositions as trophic markers in Antarctic copepods. Deep-Sea Res I 41: 915-924

Granadeiro JP, Burns MD, Furness RW (1999) Food provisioning to nestling shearwaters: why parental behaviour should be monitored? Anim Behav 57:663-671

Green K, Williams R, Green MG (1998) Foraging ecology and diving behaviour of macaroni penguins Eudyptes chry solophus at Heard Island. Mar Ornithol 26:27-34

Guinet C, Cherel Y, Ridoux V, Jouventin P (1996) Consumption of marine resources by seabirds and seals in Crozet and Kerguelen waters: changes in relation to consumer biomass 1962-85. Antarct Sci 8:23-30

Hagen W, Kattner G (1998) Lipid metabolism of the Antarctic euphausiid Thysanoessa macrura and its ecological implications. Limnol Oceanogr 43:1894-1901

Hindell MA (1988) The diet of the king penguin Aptenodytes patagonicus at Macquarie Island. Ibis 130:193-203

Hobson KA (1993) Trophic relationships among high Arctic seabirds: insights from tissue-dependent stable-isotope models. Mar Ecol Prog Ser 95:7-18

Hobson KA, Clark RG (1992a) Assessing avian diets using stable isotopes. I. Turnover of ${ }^{13} \mathrm{C}$ in tissues. Condor 94: 181-188

Hobson KA, Clark RG (1992b) Assessing avian diets using stable isotopes. II. Factors influencing diet-tissue fractionation. Condor 94:189-197

Hobson KA, Piatt JF, Pitocchelli J (1994) Using stable isotopes to determine seabird trophic relationships. J Anim Ecol 63: 786-798

Imber MJ, Nilsson RJ (1980) South Georgian diving petrels (Pelacanoides georgicus) breeding on Codfish Island. Notornis 27:325-330

Jahncke J, Garcia-Godos A, Goya E (1999) The diet of the Peruvian diving-petrel at La Vieja and San Gallan, Peru. J Field Ornithol 70:71-79

Jouventin P, Stahl JC, Weimerskirsch H, Mougin JL (1984) The seabirds of the French subantarctic islands \& Adélie Land, their status and conservation. In: Croxall JP, Evans PGH, Schreiber RW (eds) Status and conservation of the World's seabirds. ICBP Tech Publ 2:609-625

Jouventin P, Mougin JL, Stahl JC, Weimerskirsch H (1985) Comparative biology of the burrowing petrels of the Crozet Islands. Notornis 32:157-220

Jouventin P, Ridoux V, Stahl JC, Weimerskirch H (1988) La ségrégation écologique des pétrels des Iles Crozet. Rev Ecol Terre Vie 43:357-366

Kelly JF, Finch DM (1998) Tracking migrant songbirds with stable isotopes. Trends Ecol Evol 13:48-49

Ledoyer M (1995) Mysidacés (Crustacea) de Kerguelen, Crozet et Bouvet (Océan Austral) récoltés par la Japonaise, le Marion-Dufresne (1972-82) et dans des contenus stomacaux d'oiseaux. J Nat Hist 29:601-618

Lomakina NB (1966) The euphausiid fauna of the Antarctic and notal regions. In: Andriashev AP, Ushakov PV (eds) Biological Reports of the Soviet Antarctic Expedition 1955-58. Vol. 2. Israël Programme for Scientific Translations, Jerusalem, p 260-342

Marchant S, Higgins PJ (1990) Handbook of Australian, New Zealand and Antarctic Birds. Vol. 1. Oxford University Press, Melbourne

Mizdalski E (1988) Weight and length data of zooplankton in the Weddell Sea in austral spring 1986 (ANT V/3). Ber Polarforsch 55:1-72

Mizutani H, Fukuda M, Kabaya Y, Wada E (1990) Carbon isotope ratio of feathers reveals feeding behavior of cormorants. Auk 107:400-403

Mizutani H, Fukuda M, Kabaya Y (1992) ${ }^{13} \mathrm{C}$ and ${ }^{15} \mathrm{~N}$ enrichment factors of feathers of 11 species of adult birds. Ecology 73:1391-1395

Mougin JL (1985) Pétrels, pétrels-tempête et pétrelsplongeurs de l'île de Croy, îles Nuageuses, archipel des Kerguelen $\left(48^{\circ} 38^{\prime} 15^{\prime \prime} \mathrm{S}, 68^{\circ} 38^{\prime} 30^{\prime \prime} \mathrm{E}\right)$. L'Oiseau et RFO 55:313-349

Øresland V (1991) Feeding of the carnivorous copepod Euchaeta antarctica in Antarctic waters. Mar Ecol Prog Ser 78:41-47

Pakhomov EA (1993) Macroplankton of the waters contiguous to the Kerguelen Archipelago. In: Duhamel G (ed) Campagnes SKALP 1987 et 1988 aux îles Kerguelen à bord des navires 'SKIF' et 'KALPER'. Institut Français pour la Recherche et la Technologie Polaires, les Rapports des campagnes à la mer 93-01:104-112

Pakhomov EA, Perissinotto R (1996) Trophodynamics of the hyperiid amphipod Themisto gaudichaudii in the South Georgia region during late austral summer. Mar Ecol Prog Ser 134:91-100

Park YH, Gambéroni L, Charriaud E (1993) Frontal structure, water masses, and circulation in the Crozet Basin. J Geophys Res 98:12361-12385

Paulian P (1953) Pinnipèdes, cétacés, oiseaux des Iles Kerguelen et Amsterdam. Mission Kerguelen 1951. Mem Inst Rech Sci Madag Ser A Biol Anim 8:111-234

Payne MR, Prince PA (1979) Identification and breeding biology of the diving petrels Pelecanoides georgicus and $P$. 
urinatrix exsul at South Georgia. N Z J Zool 6:299-318

Prince PA, Jones M (1992) Maximum dive depths attained by South Georgia diving petrel Pelecanoides georgicus at Bird Island, South Georgia. Antarct Sci 4:433-434

Razouls C (1994) Manuel d'identification des principales espèces de copépodes pélagiques antarctiques et subantarctiques. Ann Inst Oceanogr 70:3-204

Razouls S, Koubbi P, Mayzaud P (1996) Spatio-temporal distribution of mesozooplankton in a sub-Antarctic coastal basin of the Kerguelen Archipelago (southern Indian Ocean). Polar Biol 16:581-587

Razouls S, Du Réau G, Guillot P, Maison J, Jeandel C (1998) Seasonal abundance of copepod assemblages and grazing pressure in the Kerguelen Island area (Southern Ocean). J Plankton Res 20:1599-1614

Reid K, Croxall JP, Edwards TM, Hill HJ, Prince PA (1997) Diet and feeding ecology of the diving petrels Pelecanoides georgicus and $P$. urinatrix at South Georgia. Polar Biol 17:17-24

Richer de Forges B (1977) Etude du crabe des Iles Kerguelen Halicarcinus planatus (Fabricius). Com Natl Fr Rech Antarct 42:71-133

Ridoux V (1994) The diets and dietary segregation of seabirds at the subantarctic Crozet Islands. Mar Ornithol 22:1-192

Roby DD (1989) Chick feeding in the diving petrels Pelecanoides georgicus and $P$. urinatrix exsul. Antarct Sci 1: 337-342

Schell DM, Barnett BA, Vinette KA (1998) Carbon and nitrogen isotope ratios in zooplankton of the Bering, Chukchi and Beaufort seas. Mar Ecol Prog Ser 162:11-23

Semelkina AN (1993) Development of the zooplankton in the Kerguelen Islands Region in the years 1987-88. In: Duhamel G (ed) Campagnes SKALP 1987 et 1988 aux îles Kerguelen à bord des navires 'SKIF' et 'KALPER'. Institut

Editorial responsibility: Otto Kinne (Editor),

Oldendorf/Luhe, Germany
Français pour la Recherche et la Technologie Polaires, les Rapports des campagnes à la mer 93-01:90-103

Stahl JC, Bartle JA, Jouventin P, Roux JP, Weimerskirch H (in press) Atlas of seabird distribution in the south-west Indian Ocean. Mar Ornithol

Thompson DR, Furness RW (1995) Stable-isotope ratios of carbon and nitrogen in feathers indicate seasonal dietary shifts in northern fulmars. Auk 112:493-498

Tremblay Y, Cherel Y (2000) Benthic and pelagic dives: a new foraging behaviour in rockhopper penguins. Mar Ecol Prog Ser 204:257-267

Vinogradov ME, Volkov AF, Semenova TN (1996) Hyperiid amphipods (Amphipoda, Hyperiidea) of the world oceans. Science Publishers, Lebanon, NH

Wada E, Terazaki M, Kabaya Y, Nemoto T (1987) ${ }^{15} \mathrm{~N}$ and ${ }^{13} \mathrm{C}$ abundances in the Antarctic Ocean with emphasis on the biogeochemical structure of the food web. Deep-Sea Res 34:829-841

Warham J (1990) The petrels: their ecology and breeding systems. Academic Press, London

Warham J (1996) The behaviour, population biology and physiology of the petrels. Academic Press, London

Weimerskirch H, Zotier R, Jouventin P (1989) The avifauna of the Kerguelen Islands. Emu 89:15-29

Weimerskirch H, Fradet G, Cherel Y (1999) Natural and experimental changes in chick provisioning in a longlived seabird, the Antarctic prion. J Avian Biol 30:165-174

Wilkinson L (1999) SYSTAT 9 for Windows. SPSS, Chicago

Williams R, McEldowney A (1990) A guide to the fish otoliths from waters off the Australian Antarctic Territory, Heard and Macquarie Islands. ANARE (Aust Natl Antarct Res Exped) Res Notes 75:1-173

Zavalaga CB, Jahncke J (1997) Maximum dive depths of the Peruvian diving-petrel. Condor 99:1002-1004

Submitted: March 23, 2000; Accepted: May 30, 2000

Proofs received from author(s): October 30, 2000 